\title{
DOKUMENTOITU ASIAKASLÄHTÖISYYS? \\ VAMMAISSOSIAALITYÖN PROSESSIT \\ ASIAKASDOKUMENTTIEN KUVAAMANA
}

\author{
Mari Kivistö: YTT, yliopistonlebtori, Lapin yliopisto \\ Sanna Hautala: YTT, professori, Lapin yliopisto
}

mari.kivisto@ulapland.fi; sanna.hautala@ulapland.fi

Janus vol. 28 (3) 2020, 254-272

\section{of an us}

\section{Tiivistelmä}

\begin{abstract}
Artikkelissa tarkastellaan vammaissosiaalityön prosessien asiakaslähtöisyyttä pyrkien tuottamaan moninainen kuva asiakaslähtöisyyden todentumisista, sivuuttamisista sekä näiden merkityksestä asiakkaana olevien ihmisten tilanteille. Aineistona toimivat asiakasdokumentit. Analyysissa huomio kiinnitetään ensin tapauskohtaisiin prosesseihin ja niiden etenemiseen, minkä jälkeen prosesseja analysoidaan kokonaisuutena. Tulosten perusteella sekä vammaissosiaalityön prosessien että niihin sisältyvän dokumentoinnin asiakaslähtöisyydessä on kehitettävää. Asiakaslähtöisyyden todentuminen edellyttää organisaation mahdollistavia rakenteita, työntekijän ammatillis-eettistä toimijuutta sekä asiakkaan ja työntekijän yhteisen työskentelyn dokumentointia. Asiakaslähtöisyyden näkökulmasta prosesseja on tarkasteltava asiakkaan tilanteeseen ja elämänkulkuun kiinnittyvinä kokonaisuuksina. Kehittämistä tarvitaan, koska asiakasdokumenttien kautta arvioidaan sosiaalityön asiakaslähtöisyyttä.
\end{abstract}

\section{JOHDANTO}

Asiakaslähtöisessä palvelujärjestelmässä toiminnan lähtökohtana on asiakas ja hänen tarpeensa. Asiakaslähtöisyyttä peräänkuulutetaan paremman palvelun, yhdenvertaisuuden ja osallisuuden nimissä. Kuitenkin käytäntö on usein muuta kuin käsitteen sisältämien lupausten mukaista. Mitä heikommassa asemassa olevien ihmisten tilanteista ja palveluista puhutaan, sitä kriittisemmin asiakaslähtöisyyden käytännön todentumista on syytä tarkastella. Asiakaslähtöisyyden käsite nähdäänkin tavoitekielisenä, retorisena ja ristiriitaisena sen korostaessa asiakkaan asemaa, toimijuutta ja valtaa, mutta sisältäessä toisaalta ajatuksen asiakkaan omasta vastuusta silloinkin, kun vastuunkan- tamisen edellytykset ovat heikot. Asiakaslähtöisyyden ristiriitaisuus on liitetty konsumeristis-managerialistisen ja kansalais-demokraattisen diskurssin kamppailuun keskusteluissa sosiaali- ja terveydenhuollon palveluiden järjestämisestä (Beresford \& Croft 2004; Norlamo-Saramäki 2009; myös Laitila 2010; Lindh ym. 2018). Nämä diskurssit voidaan tulkita sosiaalisiksi prosesseiksi, joilla on asiakaslähtöisyyden näkökulmasta sekä tarkoitettuja että tahattomia vaikutuksia (ks. Giddens 1989).

Asiakaslähtöisyyttä on tutkittu enemmän sen teoreettisten sisältöjen kuin varsinaisen toteutumisen näkökulmasta (Laitila 2010, 153). Oma artikkelimme fokusoituu vähän tutkittuun asiakaslähtöisyyden toteutumiseen vammaissosi- 
aalityön asiakasprosesseissa. Tarkastelemme vammaissosiaalityön prosessien asiakaslähtöisyyttä sosiaalityöntekijöiden kirjaamiin asiakasdokumentteihin nojautuen. Analyysimme tekee näkyväksi, millainen orientaatio vammaissosiaalityön prosesseista dokumenttien kautta välittyy ja ikään kuin sivutuotteena tuotamme tietoa myös siitä, mitä dokumentteihin kirjataan sekä mitä niistä ylipäätään on luettavissa asiakaslähtöisyydestä. Tutkimustehtävämme tarkentuu kysymyksiksi siitä, 1) Millaisena vammaissosiaalityön prosessien ja niiden etenemisen asiakaslähtöisyys näyttäytyy asiakasdokumenttien läpi? 2) Millaisia edellytyksiä asiakaslähtöisyydelle asettuu organisaation, työntekijän, sekä asiakkaan ja ammattilaisen välisen suhteen näkökulmasta? 3) Millainen kuva asiakaslähtöisyydestä rakentuu kokonaisuutena? Artikkeli kiinnittyy sosiaalityön ja vammaistutkimuksen traditioihin. Tutkimusmenetelminä sovellamme tapaustutkimusta ja sisällönanalyysia (Eriksson \& Koistinen 2005; Laine ym. 2007; Tuomi \& Sarajärvi 2009; Yin 2014).

Intressimme tutkia asiakaslähtöisyyttä vammaissosiaalityössä liittyy siihen kritiikkiin, jota kohdistuu vammaisten ihmisten mahdollisuuksiin saada tarvitsemiaan osallisuuttaan ja toimijuuttaan tukevia palveluita (esim. Kivistö 2014). Niin ikään tutkimuksemme taustalla on huoli vammaissosiaalityön tulevaisuudesta, resursseista ja mahdollisuuksista toteuttaa eettis-moraalista tehtäväänsä vammaisten ihmisten toimijuuden, toimintakyvyn ja välttämättömien arjen toimintojen tukemisessa (esim. Oliver ym. 2012; Romakkaniemi ym. 2018). Tulkinnassamme asiakaslähtöisyys rakentuu monitasoisesti rakenteiden ja toimijoiden välisissä vuorovaikutteisissa suhteissa. Nämä sosiaaliset rakenteet sisältävät monia kulttuurisia, osin piilossa olevia sääntöjä ja toimintatapoja, joita toimijat eri tasoilla sekä ylläpitävät että uusintavat (Giddens 1989). Myös sosiaalityössä sekä rakenteelliset tekijät että asiakkaan ja työntekijän väliset tilanteiset kohtaamiset määrittävät eri toimijoille tarjoutuvia toimijuuden sisältöjä, tiloja ja paikkoja (Laitinen \& Niskala 2016, 9). Artikkelissamme sosiaalityön sosiaalisia rakenteita edustavat asiakasprosessit ja tavat dokumentoida niitä. Myös sosiaalityölliset kohtaamiset tulevat dokumenteissa yleisellä tasolla kuvatuiksi ja paljastetuiksi (ks. Kääriäinen 2016). Anthony Giddensin (1984) rakenteistumisteoriaan viitaten tavoitteenamme on lisätä tietoisuutta vammaissosiaalityön osittain piilossa olevista sosiaalisista rakenteista tunnistamalla asiakasprosesseista tekijöitä, jotka vaikuttavat asiakaslähtöisyyden todentumiseen (ks. myös Wheeler-Brooks 2009).

\section{AsIAKASLÄHTÖISYYS}

\section{SOSIAALITYÖN TAVOITTEENA}

Yleisesti ottaen asiakaslähtöisyydellä tavoitellaan palvelujen laadun parantumista. Sosiaalityön työorientaatioissa ja vuorovaikutustilanteissa asiakaslähtöisyyden nähdään olevan sisäänrakennettuna. Asiakaslähtöisyys on sosiaalityön eettisesti kestävää toimintaa tarkoittaen muun muassa asiakkaan kuulemista ja hänen itsemääräämisoikeutensa kunnioittamista, yksilöllisen tilanteen huomioimista, sekä asiakasprosessin etenemistä asiakkaan esille nostamien tarpeiden lähtökohdista käsin (Talentia 2017). 
Vaikka asiakaslähtöisyys on nykykeskusteluissa nostettu erityiseksi arvoksi niin asiantuntija- kuin julkisissa keskusteluissa, se on käsitteenä melko tuore (esim. Pohjola 2017). Asiakaslähtöisyyskeskustelujen juuret paikantuvat muun muassa 1960 ja 1970-luvun vammaisliikkeiden emansipaatioon (Järvikoski ym. 2009; Tarvainen 2017) sekä sosiaalihuollon toimintatapoihin kohdistuneeseen kritiikkiin (Juhila 2006). 1990-luvun lopulta lähtien asiakaslähtöisyyden ja asiakasosallisuuden käsitteet ovat olleet valtavirtaa sekä politiikan että palvelujärjestelmien retoriikassa (Beresford \& Croft 2004, 61). Kuitenkin, vaikka analyyttinen keskustelu asiakkaan asemasta on alkanut suhteellisen myöhään, on asiakaslähtöisyyden idea ollut olemassa sosiaalityön käytännöissä jo ennen sen varsinaista käsitteellistämistä ja sanoittamista (Norlamo-Saramäki 2009).

Asiakaslähtöisyyden käsite vaikuttaa helppotajuiselta, mutta siihen kohdistuu paljon kritiikkiä. Tuija NorlamoSaramäki (mt., 43) on huomauttanut asiakaslähtöisyyden jääneen käsitteellisen epämääräisyytensä vuoksi osittain retoriikaksi (myös Laitila 2010). Myös työntekijöiden kyvyn hahmottaa abstraktin asiakaslähtöisyyden sisältöä sosiaalityön käytännöissä on todettu olevan vaihteleva (Kokko 2018, 135). Kritiikki on kohdistunut myös siihen, että palvelujärjestelmät ilmoittavat tavoittelevansa asiakaslähtöisyyttä, mutta jättävät järjestelmää edustaville työntekijöille vain vähän valtaa ja mahdollisuuksia sen toteuttamiseen (Tuusa 2005; myös Beresford \& Croft 2004). Anthony Giddens (1989) onkin todennut, että osa sosiaalisen rakenteen uusintamisen seurauksista on ennalta arvaamattomia.
Asiakaslähtöisyyden vahvistumisen sijaan esimerkiksi konsumeristis-managerialistinen diskurssi on tuottanut riskin toimintatapojen organisaatiolähtöisyyden vahvistumiselle hallinnollisen puheen, erilaisten ohjeistusten, systematisoinnin ja standardisoinnin sekä taloudellisen tehokkuuden vaatimuksen lisääntymisen myötä (Beresford \& Croft 2004; Laitila 2010; Närhi ym. 2014). Esteenä asiakkaan aseman aidolle vahvistamiselle on nähty muun muassa vallan jakamisen vaikeus sekä sosiaalityön ammatillisen identiteetin ytimen katoaminen ja managerialismille alistaminen (Beresford \& Croft 2004; Niemi 2016).

Asiakaslähtöisyydellä on lainsäädännöllinen ja poliittinen perustansa. Sosiaalihuollon asiakaslain (812/2000) tarkoituksena on edistää asiakaslähtöisyyttä sekä asiakassuhteen luottamuksellisuutta, ja sosiaalihuoltolain (1301/2014) tarkoituksena on vahvistaa asiakaskeskeisyyttä sekä asiakkaan oikeutta hyvään kohteluun ja palveluun. Hallituksen "Palvelut asiakaslähtöisiksi" -kärkihankkeessa (2016-2018) painotettiin asiakkaan osallisuuden vahvistamista yksilöllisten ja joustavien palveluprosessien myötä, mutta myös asiakkaan omaa vastuuta hyvinvointinsa suhteen. Asiakaslähtöisyyden korostaminen kiinnittyy myös muuttuvaan yhteiskunnalliseen toimintaympäristöön, kuten sosiaali- ja terveyspalvelujen järjestämiseen. Valtamedioissa käydään keskustelua vammaisten oikeuksista vaikuttaa palveluihin sekä palveluiden uudelleen organisoitumisesta ja uusiin toteuttamistapoihin liittyvistä riskeistä Muun muassa vammaisten arjen kannalta välttämättömien asumis- ja kuljetuspalvelujen toteuttamisen tapoihin 
ja sisältöihin on nähty lisääntyneen kilpailutuksen vaikuttavan kielteisesti. Uutisoinnit tekevät näkyväksi asiakaslähtöisyyden retorisen ulottuvuuden ja epäkohtien välisen ristiriidan, ja jopa vammaisten palveluiden heikkenemisen yksilön vastuun ja markkinatalouden liiallisen painottamisen seurauksena.

\section{SOSIAALITYÖN DOKUMENTOINNIN LÄHTÖKOHDAT}

Vaikka sosiaalityössä on laadittu asiakasasiakirjoja jo 1800-luvun loppupuolelta alkaen (Doyle 2010; Poikela 2010), on dokumentointi vasta viime vuosina nostettu yhdeksi sosiaalityön keskeisimmistä työtehtävistä. Dokumentoinnin nykymerkityksestä todistaa sen ohjaaminen niin lainsäädännössä, sosiaalityön koulutuksessa kuin kehittämishankkein ${ }^{1}$ (Savaya 2010; Kääriäinen 2016). Tutkimusta sosiaalityön dokumentoinnista on tehty muun muassa lasten ja perheiden (Kääriäinen 2003; Poikela 2010) sekä mielenterveystyön (Günther ym. 2013; Günther 2015) näkökulmasta. Kirsi Günther kollegoineen (2013) liittää asiakaslähtöiseen dokumentointiin olemassa olevien kirjaamiskäytäntöjen tiedostamisen ja reflektoinnin, asiakaslähtöisen kielenkäytön sekä asiakkaan osallisuuden ja oman asiantuntijuuden näkyväksi tekemisen. Ritva Poikela (2010) on osoittanut asiakaslähtöisyyden toteutumisen jäävän kuitenkin vajaaksi, koska esimerkiksi asiakassuunnitelmia laaditaan yleensä institutionaalisen palveluvalikon ehdoilla asiakkaiden omien merkityksenantojen jäädessä vähäisemmälle huomiolle (myös Kivistö 2014).
Monelle vammaissosiaalityön asiakkaalle asiakasdokumenttien kirjausten perusteella haetut, arvioidut, suunnitellut ja järjestettäviksi päätetyt palvelut ovat heidän arkensa sujumisen kannalta elintärkeitä. Vammaissosiaalityössä on myös asiakkaita, jotka ovat erityisen haavoittuvassa asemassa sen suhteen, miten he saavat tarpeensa esille tai äänensä kuuluvaksi. Vammaissosiaalityöhön ja siellä tapahtuvaan dokumentointiin kohdistuvaa tutkimusta on tehty harvalukuisesti, eikä tutkimus ole kohdistunut asiakasprosessiin kokonaisuutena. Ulla Tiililä (2007) on tutkinut vammaispalvelujen kuljetuspalvelupäätöksiä kielenkäytön näkökulmasta todeten niiden olevan vaikeaselkoisia ja massatuotettuja, vaikkakin poikkeuksittain myös selkeitä ja yksilöllisiä.Vammaissosiaalityön palvelusuunnitelmat on puolestaan nähty tiukasti strukturoituina sekä järjestelmä- ja ongelmakeskeisinä (mt.; Kivistö 2014).

Dokumentoinnin käsitteeseen liittyy assosiaatio pyrkimyksestä asiakkaiden tilanteiden kirjalliseen kuvaamiseen siten kuin ne todellisuudessa ilmenevät. Sosiaalihuollon dokumentteihin ei kirjata työntekijöiden implisiittisiä oletuksia. Toisaalta asiakasdokumenteilla rakennetaan todellisuutta dokumentaation toimiessa sosiaalityössä yhtenä tavoitellun muutoksen välineenä. Parhaimmillaan dokumentointi kuvaa myös sosiaalityön vaikutuksia. Siksi on tärkeää ymmärtää asiakasdokumenttien merkitys osana sosiaalityön prosessia ja tiedonmuodostusta. (Kääriäinen 2003; 2016.) Asiakirjoihin dokumentoimalla sosiaalityössä tehdystä työstä muodostuu virallista tietoa, jota sosiaalityön prosessin vaiheesta riippuen käytetään arvioinnissa, suunnittelussa ja päätök- 
senteossa. Dokumentointi on myös tapa tehdä sosiaalityötä näkyväksi asiakkaille, kollegoille ja päättäjille. Myös asiakkaan oman prosessinhallinnan, osallisuuden ja oikeuksien toteutumisen näkökulmasta tilanteeseen liittyvien oleellisten asioiden kirjaaminen on merkityksellistä. Sosiaalityölle täsmällinen dokumentointi on lisäksi eettinen velvollisuus. (Kuusisto-Niemi \& Kääriäinen 2005; Kananoja 2017; Reamer 2017; Kivistö ym. 2019.) Dokumentointikäytännöt kuitenkin vaihtelevat dokumenttien voidessa olla esimerkiksi niin niukkoja, etteivät ne tavoita ihmisten todellisia tilanteita.

Tietojärjestelmien toimivuudella on merkitystä sosiaalityön dokumentoinnin onnistumiselle, mutta erityisesti kansainvälisessä tutkimuskirjallisuudessa on kuvattu kokemuksia tietojärjestelmien kehittämisestä sosiaalityön tavoitteiden sijaan managerialismin näkökulmasta (Gillingham \& Graham 2016; Eubanks 2017; Salovaara 2018). Sosiaalityön dokumentointia on syytä tarkastella kriittisesti myös sen suhteen, missä määrin sitä tehdään asiakkaan tilanteen ratkaisemisen vuoksi ja miltä osin järjestelmälähtöisistä syistä. Kysyttävä on myös, arvioidaanko ja dokumentoidaanko palvelutarpeita asiakkaiden yksilöllisistä elämäntilanteista käsin sen sijaan, että elämäntilanteet asetetaan standardisoitujen, mekaanisten ja byrokraattisten lomakkeiden ja toimintatapojen kohteeksi (Beresford \& Croft 2004, 63). Teknis-hallinnollisen diskurssin pyrkiessä hallitsemaan on muistettava, että sosiaalityön dokumentointi on osa asiakastyötä (Poikela 2010, 3-4).

Sosiaalityön prosesseissa ja niiden dokumentoinnissa lainsäädännön ohjaus- valta on suuri (Kääriäinen 2016). Laissa sosiaalihuollon asiakasasiakirjoista (254/2015) kirjaamisella tarkoitetaan yksinkertaisuudessaan "merkintöjen tekemistä asiakirjaan". Sosiaalihuollon ammatillinen henkilöstö on velvollinen viipymättä kirjaamaan sosiaalihuollon järjestämisen, suunnittelun, toteuttamisen, seurannan ja valvonnan kannalta riittävät ja tarpeelliset tiedot. Vammaispalvelulain (380/1987) perusteella palvelu- ja tukitarpeiden selvittäminen on aloitettava viimeistään seitsemäntenä arkipäivänä yhteydenotosta. Palvelusuunnitelma on laadittava viivytyksettä ja suunnitelmaa tarkistettava, jos vammaisen henkilön palvelutarpeessa tai olosuhteissa tapahtuu muutoksia. Myös päätökset on tehtävä viivytyksettä, ja viimeistään kolmen kuukauden kuluessa hakemuksen esittämisestä.

Koska dokumentointi on sosiaalityön keskeinen työtehtävä ja työväline, on sosiaalityön dokumentointikäytäntöjen ja -osaamisen kehittäminen tärkeää (Kääriäinen 2016, 197; myös Savaya 2010). Sosiaalityön dokumenteista on osoitettu puuttuvan usein sekä perustietoja että tietoja interventioiden vaikutuksesta asiakkaiden elämäntilanteisiin. Dokumentointi on voinut myös olla epäselvää ja sekavaa. (Savaya 2010.) Tarja Kemppaisen ja kumppaneiden (2018, 195-196) mukaan sosiaalialan työntekijät kokevat dokumentoinnin suhteen epävarmuutta ja vahvistamisen tarpeita osana laajempaa prosessin hallintaa. Totuudenmukainen, kattava, jatkuva ja eheä dokumentointi nähdäänkin hyödylliseksi sosiaalityön palvelutarpeen arvioinnille ja palvelusuunnittelulle, mutta myös laajemmin sosiaalityön vaikutusten ja palvelujen järjestämisen tarpeen arvi- 
oinnille (Reamer 2017). Vammaisten ihmisten näkökulmasta asiakaslähtöinen dokumentointi toimii myös välineenä oikeuksia korostavan vammaispolitiikan toimeenpanolle (Autio \& NurmiKoikkalainen 2015, 234).

\section{TUTKIMUKSEN TOTEUTTAMINEN}

\section{Aineisto, konteksti ja aineiston lukutapa}

Aineistonamme ovat seitsemän 20-46 -vuotiaan liikunta- tai näkövammaisen henkilön yhden asiakasprosessin dokumentit. Henkilöiden asiakkuus vammaissosiaalityössä oli kestänyt jo vuosia, mutta rajasimme tarkastelun kunkin viimeiseen vammaissosiaalityön prosessiin. Aineisto rajautuu henkilökohtaista apua koskeviin prosesseihin. Aineiston dokumentit koostuivat hakemuksista, asiakaskertomuksista, palvelusuunnitelmista ja päätöksistä. Hakemus on asiakkaan täyttämä lomake, jonka vireille tulosta ryhdytään laskemaan päätöksenteolle annettua enintään kolmen kuukauden määräaikaa. Aineistomme hakemuksista osa oli tehty vapaamuotoisesti virallisen lomakkeen sijaan ja osa palvelutarpeen arvioista oli dokumentoitu erillisen asiakirjan sijaan osana palvelusuunnitelmia tai asiakaskertomuksia. Luonteeltaan asiakasdokumentit sijoittuvat yksityisen ja hyvin henkilökohtaisen, mutta toisaalta virallisen ja institutionaalisen rajamaille (Bryman 2008).

Ymmärrämme asiakaslähtöisyyden palvelujärjestelmän tavoitteellisena tilana, jolla tarkoitetaan ennen kaikkea sitä, että asiakkaiden yksilölliset tarpeet asetetaan ensisijaiseksi palvelujen järjestämisen lähtökohdaksi. Asiakaslähtöisyys ei tarkoita sellaista asiakaskeskeisyyttä, jossa asiakas määrittäisi yksin omat palvelunsa, vaan asiakaslähtöisyyden ideassa korostuu asiakkaan ja ammattilaisen yhteistyö, dialoginen vuorovaikutus ja kumppanuus (Beresford \& Croft 2004; Kemppainen ym. 2010; Niemi 2016). Sosiaalityön prosessin tulkitsemme asiakasta ja hänen elämäntilannettaan koskevaksi, erilaisia tapahtumia sisältäväksi tapauskohtaiseksi ja tavoitteelliseksi työskentelyksi, jonka päämääränä on positiivinen muutos asiakkaan tilanteessa (Toikko 2009, 272-273; ks. myös Compton ym. 2005).

Vammaissosiaalityössä painottuvat tapauskohtainen työ, yksilökohtainen palveluohjaus sekä hallinnollinen, juridinen ja palvelujärjestelmään liittyvä osaaminen. Vammaissosiaalityön on todettu olevan paineistettua nykyisessä talouden ja tehokkuuden eetoksessa (Kivistö 2014; Laisi ym. 2016). Vammaissosiaalityön prosessi noudattaa yleistä sosiaalityön prosessia, jonka esimerkiksi Compton ja kumppanit (2005) ovat jakaneet kontakti-, sopimus-, toiminta- ja arviointivaiheeseen. Hallinnollisesta näkökulmasta prosessi käynnistyy vireille tulosta,jonka jälkeen tehdään palvelutarpeen arvio ja palvelusuunnitelma yhteistyössä asiakkaan sekä tarvittaessa hänen läheistensä ja muiden ammattilaisten kanssa. Palvelupäätös perustuu sitä edeltäneeseen tiedonkeruuseen ja suunnitteluun. Koska vammaissosiaalityössä asiakassuhteet ovat pitkiä, jopa elämän mittaisia, ovat myös tutkimuksemme kohteena olevat prosessit tosiasiallisesti pidemmän asiakkuusprosessin osaprosesseja tai asiakaslähtöisesti sanoittaen asiakkaan elämänkulkuun sisältyviä elämäntilanteita. 


\section{Analyysin kulku}

Nojaudumme tapaustutkimuksen traditioon, jossa tarkastelun kohteena on usein jokin tapahtumakulku tai prosessi. Tapaustutkimuksessa voidaan käyttää erilaisia menetelmiä. (Laine ym. 2007; Yin 2014.) Oma analyysimme eteni limittäisin vaihein ja aluksi aineistolähtöisesti. Ensimmäisessä vaiheessa (kuvio hahmottamaan tapauskohtaisten prosessien erilaisuutta.

Seuraavaksi siirryimme teoriasidonnaiseen, tapauskohtaiset prosessit kokoavaan sisällön analyysiin (kuvio 2). Siinä hyödynsimme Minna Laitilan (2010) jäsennystä asiakaslähtöisyydestä kolmella eri tasolla; palvelujärjestelmää edustavan organisaation toimintatavat,

\begin{tabular}{|c|c|c|c|c|}
\hline PROSESSIN NIMEÄMINEN & \multicolumn{3}{|c|}{ PROSESSIN AIKAJANA } & KESTO \\
\hline $\begin{array}{l}\text { Essi: Märääaikaisen palvelun } \\
\text { jatko edellyttää asiakkaan } \\
\text { toimijuutta }\end{array}$ & $\begin{array}{l}\text { Hakemus } \\
18.3 .\end{array}$ & $\begin{array}{l}\text { Päătös } \\
21.3 .\end{array}$ & & $3 \mathrm{pv}$ \\
\hline $\begin{array}{l}\text { Pirjo: Muuttuva elämäntilanne } \\
\text { vaatii ennakointia ja oikea- } \\
\text { aikaisuutta }\end{array}$ & $\begin{array}{l}\text { Suunni- } \\
\text { telma } 26.1 \text {. }\end{array}$ & $\begin{array}{l}\text { Hakemus } \\
24.2 .\end{array}$ & & $2 \mathrm{kk} 12 \mathrm{pv}$ \\
\hline $\begin{array}{l}\text { Esko: Joustavasta alusta } \\
\text { huolimatta hallinnollinen } \\
\text { prosessi voi venyä }\end{array}$ & $\begin{array}{l}\text { Hakemus } \\
24.2 \text {. }\end{array}$ & & Päăt & $2 \mathrm{kk} 8 \mathrm{pv}$ \\
\hline $\begin{array}{l}\text { Jarmo: Monivaiheinen ja } \\
\text { neuvotteleva prosessi }\end{array}$ & $\begin{array}{l}\text { Hakemus } \\
8.3 \text {. }\end{array}$ & $\begin{array}{l}\text { Asiakasker- } \\
\text { tomus 5.4. }\end{array}$ & sasker- & $2 \mathrm{kk} 25 \mathrm{pv}$ \\
\hline $\begin{array}{l}\text { Jaana: Ilman ajoissa saatavaa } \\
\text { informaatiota oikeuksien } \\
\text { toteutuminen pitkittyy }\end{array}$ & $\begin{array}{l}\text { Suunni- } \\
\text { telma 2.6. }\end{array}$ & & $\begin{array}{l}\text { Hakemus } \\
16.10 .\end{array}$ & \\
\hline $\begin{array}{l}\text { Anssi: Yhteistyöllä prosessi } \\
\text { etenee sujuvasti }\end{array}$ & $\begin{array}{l}\text { Hakemus } \\
1.6 .\end{array}$ & $\begin{array}{l}\text { Päätös } \\
21.6 .\end{array}$ & & $20 \mathrm{pv}$ \\
\hline $\begin{array}{l}\text { Saara: Nopea prosessi on } \\
\text { m ahdollinen }\end{array}$ & $\begin{array}{l}\text { Hakemus } \\
17.7 .\end{array}$ & $\begin{array}{l}\text { Päätös } \\
18.7 .\end{array}$ & & $1 \mathrm{pv}$ \\
\hline
\end{tabular}

Kuvio 1. Aineiston tapauskohtaisten prosessien kuvaus ja analyysin ensimmäinen vaihe

1) tavoitteena oli tunnistaa dokumenteista ihminen tilanteessaan ja antaa tapaukselle subjektius. Kunkin henkilön tapauskohtainen prosessi nimettiin ja prosesseista kirjoitettiin lyhyet tapauskuvaukset. Lisäksi tehtiin aikajanat prosessien etenemisen havainnollistamiseksi. Prosessien mallintaminen auttaa organisaatiota edustavan ammattilaisen ja asiakkaan välinen yhteistyösuhde, sekä työntekijän asiakaslähtöinen toiminta ja työtapa. Analyysin taustalta on tunnistettavissa myös Anthony Giddensin (1989) tulkinta sosiaalisen todellisuuden rakentumisesta rakenteen (organisaatio) ja toimijoiden (ammattilainen, asiakas) välisessä vuorovaikutuksessa. 


\begin{tabular}{|c|c|c|}
\hline $\begin{array}{l}\text { ASIAKAS- } \\
\text { LÄHTÖISYYS }\end{array}$ & $\begin{array}{l}\text { PELKISTETYT AINEISTOHAVAINNOT } \\
\text { (asiakaslähtöisyyttä edistävät ja estävät tekijät) }\end{array}$ & $\begin{array}{l}\text { ASIAKASLÄHTÖISEN PROSESSIN } \\
\text { EDELLYTYKSET }\end{array}$ \\
\hline $\begin{array}{l}\text { Organisaation rakenteellisina } \\
\text { toimintatapoina }\end{array}$ & $\begin{array}{l}\text { + prosessit käynnistyvät asiakkaiden tarpeista } \\
\text { + nopeat prosessit mahdollisia } \\
\text { + lopputuloksena palvelun saaminen } \\
\text { - vaade asiakkaan ja läheisten toimijuudelle } \\
\text { - usein moniportainen päätöksenteko } \\
\text { - prosessit usein pitkiä, epäselviä ja byrokraattisia } \\
\text { - ennakointi vähäistä } \\
\text { - oikea-aikaisuuden puutteet } \\
\text { - seurannan/yhteydenpidon vähäisyys } \\
\text { - työntekijöiden osaamisen vajaa hyödyntäminen }\end{array}$ & $\begin{array}{l}\text { Asiakkaan ja ammattilaisen toiminnan ja } \\
\text { yhteistyön mahdollistaminen } \\
\text { Prosessien ja dokumentoinnin } \\
\text { rakenteiden asiakaslähtöisyys }\end{array}$ \\
\hline $\begin{array}{l}\text { Ammattilaisen ja asiakkaan } \\
\text { välisenä yhteistyösuhteena }\end{array}$ & $\begin{array}{l}\text { + henkilökohtainen asiakkaan kuuleminen, jossa } \\
\text { tarvittaessa läheiset mukana } \\
\text { + avoimen neuvottelun toteutuminen } \\
\text { + useampien tapaamisten mahdollisuus } \\
\text { + työntekijän asiantuntijuuden antaminen } \\
\text { käytettäväksi asiakkaan tilanteen ratkaisemisessa } \\
\text { + hakemuksen yhdessä tekeminen } \\
\text { - avoimen informaation antamattomuus eri } \\
\text { mahdollisuuksista ja vaihtoehdoista } \\
\text { - dialogin dokumentoimattomuus } \\
\text { - sitoutumattomuus asiakkaiden tilanteiden } \\
\text { ratkaisemiseen myös dokumentoidusti }\end{array}$ & $\begin{array}{l}\text { Dokumentoitu dialogisuus } \\
\text { Dokumentoitu yhteistyö }\end{array}$ \\
\hline $\begin{array}{l}\text { Ammattilaisen toimintana ja } \\
\text { työtapana }\end{array}$ & $\begin{array}{l}\text { + yksilöllinen joustaminen tarvittaessa } \\
\text { + nopea toiminta asiakkaan tilanteen vaatiessa } \\
\text { + asiakkaan neuvonta ja ohjaus } \\
\text { + riittävän kattava tarpeiden arviointi } \\
\text { + työntekijän vastuiden dokumentointi } \\
\text { - työntekijän aktiivinen toimijuus ei toteudu koko } \\
\text { prosessin ajan } \\
\text { - puutteet dokumentoinnin eheydessä ja } \\
\text { täsmällisyydessä } \\
\text { - liian suppea tarpeiden arviointi }\end{array}$ & $\begin{array}{l}\text { Ammatillis-eettinen toimijuus ja sen } \\
\text { dokumentointi }\end{array}$ \\
\hline
\end{tabular}

Kuvio 2. Tapausten kokoaminen ja analyysin toinen vaihe

Kuviossa esitetyt jäsentelyt asiakaslähtöisyydestä muodostavat tuloslukujemme rungon. Otteet analyysin ensimmäisessä vaiheessa kirjoitetuista tapauskuvauksista pääsevät ääneen tutkimustulosten esittämisen lomassa. Tapauskuvaukset pyrkivät olemaan todenmukaisia, vaikka niihin sisältyy väistämättä myös tutkijan tulkintaa (ks. Eriksson \& Koistinen 2005, 37). Hyödynnämme tapauskuvausten lisäksi tulostemme konkretisoinnissa myös muutamia suoria lainauksia asiakasdokumenteista.

\section{Eettiset lähtökohdat}

Sekä tapaustutkimus että asiakasdokumenttien tutkimus on eettisesti haastavaa ja edellyttää huolellisuutta tutkimuksen toteuttamisen kaikissa vaiheissa. Aineistona oleviin tapauksiin liittyvät tutkimusluvat haettiin kahdesta, eri puolilla Suomea sijaitsevasta vammaispalveluorganisaatiosta. Toisessa organisaatioista toimii myös tutkimuseettinen toimikunta, jossa tutkimuslupahakemus käsiteltiin. Tutkimuksessa on huomioitu rekisteritutkimukseen, 
henkilötietojen käsittelyyn ja aineiston hallintaan liittyvät eettiset vaatimukset. Dokumentit kuuluvat tutkimushankkeessa aiemmin haastatelluille henkilöille, jotka oli rekrytoitu tutkimukseen organisaatioiden avulla, vapaaehtoisuuden pohjalta. Haastatelluilta pyydettiin suostumus myös asiakasdokumenttien tutkimuskäyttöön. Organisaation edustaja poimi saamansa ohjeistuksen perusteella asiakasdokumentit tietojärjestelmästä.

Koska teemme tapauskohtaista analyysia, on ihmisten anonymiteetin suojaamiseen kiinnitettävä erityistä huomiota. Tutkimussuunnitelman mukaisesti alkuperäisiin asiakasasiakirjoihin pääsy oli vain yhdellä tutkijalla (Mari Kivistö). Tapauskuvauksissa ja prosessien mallinnuksissa asiakkaiden nimien lisäksi prosessin eri vaiheisiin liittyvät päivämäärät on muutettu, mutta prosessien kokonaiskestot ja vaiheiden väliset aikaikkunat vastaavat alkuperäisiä.

\section{ORgANISAATIO ASIAKASLÄHTÖISYYDEN MAHDOLLISTAJANA}

Asiakaslähtöisyys lähtee rakenteista ja niiden mahdollistavuudesta tai rajoittavuudesta (Beresford \& Croft 2004; Romakkaniemi ym. 2018). Analyysimme perusteella organisaation toimintatapojen asiakaslähtöisyys edellyttää asiakkaan ja työntekijän toiminnan mahdollistamista sekä prosessien ja dokumentoinnin asiakaslähtöisiä rakenteita. Aineistossamme tapauskohtaisten prosessien käynnistyminen liittyi yleensä asiakkaan toimintakyvyssä tai elämäntilanteessa tapahtuneeseen, palvelutarpeisiin vaikuttavaan muutokseen. Organisaation asiakaslähtöisyys toteutuukin siinä mielessä, että asiakkailla on mahdollisuus ilmaista tarpeitaan ja laittaa asioita vireille sen sijaan, että prosessit käynnistyisivät pelkästään organisaation toimesta (vrt. Kokko 2018).

Sellaiset rakenteellisesti asiakaslähtöiset toimintatavat, joissa organisaatiosta käsin pidetään yhteyttä asiakkaisiin, mahdollistavat muun muassa asiakkaiden palvelutarpeiden muutosten ennakoinnin sekä dialogisemman vuorovaikutuksen asiakkaan ja palvelujärjestelmän välillä.Vammaissosiaalityöllisen aineistomme perusteella palvelujen asiakkaiden tarpeisiin vastaamista ei kuitenkaan organisaation aloitteesta aina systemaattisesti seurata (myös Kivistö ym. 2019; vrt. Kokko 2018). Aineistossamme uusien prosessien käynnistyminen edellytti vammaisten asiakkaiden itsensä ja osassa tapauksista myös heidän läheistensä toimijuutta; toisin sanoen sellaista velvoittavuutta ja vastuuttamista, jota ei lähtökohtaisesti voida tulkita asiakaslähtöiseksi toiminnaksi (myös Niemi 2016; Kokko 2018). Asiakkaan velvollisuutta uusien prosessien käynnistämisessä kuvaa Essin tapaus, jossa oli kyse henkilökohtaisen avun määräaikaisen päätöksen päättymisestä. Asiakkaan vastuu palvelun jatkon hakemiseksi oli dokumentoitu myös Essin uuteen määräaikaiseen päätökseen.

Asiakas vastaa itse henkilökohtaisen avun kustannuksista päatöksen voimassaoloajan päätyttyä -- Asiakkaan on otettava yhteyttä oman alueen vammaispalvelutoimistoon hyvissä ajoin ennen päätöksen päättymispäivää ja haettava palvelulle jatkoa undella hakemuksella. Asiakkaan tulee huomioida asian käsittelyaika. (Päätös 21.3.2017) 
Organisaatio, jonka toimintatavat mahdollistavat prosessien sujuvan etenemisen, voidaan tulkita rakenteiltaan asiakaslähtöiseksi. Aineistomme prosessien kesto vaihteli yhdestä vuorokaudesta lähes kolmeen kuukauteen, yksittäistapauksessa jopa puoleen vuoteen. Pitkät prosessit liittyivät yleensä laajaa harkintaa vaativiin tilanteisiin, joissa vireille laitettu palvelu myös edellytti organisaatiolta merkittävää taloudellista panostusta. Toisaalta prosessi saattoi olla pitkä myös tapauksessa, jonka arvioidut taloudelliset vaikutukset olivat vähäisempiä. Prosessien kulloistakin kestoa ja siihen liittyviä valintoja ei ollut dokumenteissa ennakoitu eikä perusteltu.

Prosessit eivät asiakasdokumenttien perusteella näytä etenevän aina oikeaaikaisesti suhteessa asiakkaan elämäntilanteen muutoksiin. Pirjo oli muuttamassa yksin asumaan, mutta joutui dokumenttien perusteella selviytymään kahden kuukauden ajan ilman hakemiaan henkilökohtaisen avun lisätunteja. Tässä tapauksessa on kysyttävä, miten vammaissosiaalityön prosesseissa voitaisiin paremmin ennakoida asiakkaiden muuttuviin elämäntilanteisiin liittyviä palvelutarpeiden muutoksia.

Pirjon palvelusuunnitelmaa tarkistettiin asumistilanteessa edessä olevan muutoksen vuoksi. Pirjo tarvitsi henkilökohtaisen avun lisätunteja voidakseen ryhtyä asumaan $y k$ sin ensimmäistä kertaa elämässään. Suunnitelmaan kirjattiin asioita, joissa Pirjo tarvitsi toisen henkilön apua. Suunnitelman laatimisen jälkeen Pirjo oli kuitenkin, todennäköisesti sosiaalityöntekijän pyynnöstä, tehnyt vielä erillisen hakemuksen, jossa selosti tarvettaan seikkaperäisesti ja myös määrällisesti arvioiden. Hakemus oli laitettu vireille vasta muutama viikko muuton jälkeen. Kokonaisuudessaan prosessi kesti noin kaksi ja puoli kuukautta päättyen lopulta sosiaalityöntekijän tekemään myönteiseen päätökseen. Prosessin kesto pitäytyi lain mukaisessa kolmen kuukauden määräajassa, mutta Pirjo sai hakemansa lisäavun käyttöönsä vasta kuukausia tarpeen alkamisen jälkeen. (Tapauskuvaus Pirjo)

Asiakaslähtöinen organisaatio pyrkii minimoimaan turhan byrokratian ja toteuttamaan päätöksentekoprosessin asiakkaalle läpinäkyvästi, informatiivisesti ja asianmukaisesti dokumentoidusti. Asiakkaalle tehdään selväksi, miten prosessi tulee etenemään ja ketkä osallistuvat asian käsittelyyn. Osa aineistomme tapauksista ilmensi kuitenkin moniportaisia päätöksentekoprosesseja. Niissä varsinainen päätöksentekijä oli palvelupäällikkö tai johtava sosiaalityöntekijä selvityksen tehneen ruohonjuuritason työntekijän sijaan, jolloin asiakas on vaarassa jäädä päätöksentekovaiheessa oman prosessinsa ulkopuolelle. Eskon tapauksessa perustason työntekijä toimi kyllä asiakaslähtöisesti hakemuksen vireilletulon vaiheessa, mutta tämän jälkeen prosessi moniportaistui.

Esko haki pienehköä henkilökohtaisen avun lisätuntimäärää toimintakyvyssään tapahtuneen heikentymisen vuoksi. Sosiaalityöntekijä muutti asiakkaan tarpeesta johtuvasta syystä kotikäyntiaikaa joustavasti parin päivän päähän alun perin sovitusta. Työntekijä myös otti hakemuksen joustavasti suullisesti vastaan kotikäynnillä. Joustavasta alustaan huolimatta prosessi kesti kokonaisuutena yli kaksi kuukautta, eikä asiakasdokumenteista selviä, mitä kaikkia vaiheita päätöksen tekeminen prosessin aikana vaati. Toisaalta dokumenteista käy esille, että sosiaalityöntekijä pyysi kotikäynnin yhteydessä asiakasta toimittamaan 
uuden lä̈kärinlausunnon tilanteestaan, ja tämän asiakas toimittikin jo viikon kuluessa. Koska lopullisen myönteisen päätöksen teki johtava sosiaalityöntekijä, on prosessin eteneminen todennäköisesti riippunut eri työntekijöiden aikatauluista ja heidän välisistään neuvotteluista. (Tapauskuvaus Esko)

Ylimääräinen byrokratia on ristiriidassa asiakaslähtöisyyden kanssa. Organisaatioiden ja prosessien rakenteellista asiakaslähtöisyyttä voisi vahvistaa vahvempi luottamus sosiaalityöntekijöiden osaamiseen ja harkintaan myös päätöksenteossa (myös Romakkaniemi ym. 2018). Sosiaalityön ytimessä oleva, asiakkaan ja työntekijän luottamuksellinen suhde voi kolhiintua, mikäli organisaation prosesseja koskevat toimintaohjeet eivät mahdollista asiakkaan ja työntekijän aitoa yhteistyötä koko prosessin ajan.

\section{DiALOGIN JA YHTEISTYÖN DOKUMENTOINTI}

Käsitys asiakaslähtöisyydestä sosiaalityössä perustuu ennen kaikkea työntekijän ja asiakkaan väliseen jaettuun asiantuntijuuteen, kumppanuuteen, yhteiseen työskentelyyn, dialogiin ja yhteiseen ymmärrykseen (Beresford \& Croft 2004; Juhila 2006; Laitila 2010; Pohjola 2017). Vammaissosiaalityössä asiakkaan ja ammattilaisen yhteistyötä mahdollistavat muun muassa kotikäyntien tekeminen ja asiakkaiden henkilökohtainen kuuleminen. Molemmat toimintatavat tulivat esille myös omassa aineistossamme.

Yhteistyösuhteen olemassaololle ja tunnustamiselle on tärkeää myös sen dokumentoiduksi tuleminen, mutta aineistossamme yhteisen työskentelyn ja dialogisuuden dokumentointi oli varsin vähäistä. Kuitenkin Jarmon asiakasdokumenteissa voi tulkita tulevan esille ammattilaisen ja asiakkaan välistä dialogia. Koska asiakaslähtöisyys ei tarkoita sitä, että asiakas yksin määrittäisi omat palvelunsa, voi prosessi muodostua pitkäksikin neuvotteluksi, kuten kyseisessä tapauksessa, johon sisältyi muun muassa kaksi sosiaalityöntekijä-ohjaaja-työparin tekemää kotikäyntiä.

Jarmo oli hakenut lisää henkilökohtaisen avun tunteja etenevään sairauteensa liittyneen toimintakyvyn heikkenemisen vuoksi. Ensimmäinen kotikäynti tehtiin noin kuukausi hakemuksen saapumisen jälkeen. Kotikäynnillä olivat läsnä Jarmo, hänen avustajansa sekä vammaispalveluista sosiaalityöntekijä ja ohjaaja. Asiakaskertomukseen on kirjattu runsaasti työntekijöiden toteuttamaa, henkilökohtaisen avun käyttöön liittyvää ohjausta ja neuvontaa. Työntekijöiden ammatillisen arvion mukaan asiakkaan henkilökohtaisen avun tarve oli pienempi kuin asiakkaan hakemuksessaan esittämä. Toisaalta asiakaskertomukseen on kirjattu myös asiakkaan mielipiteitä ja toiveita. (Tapauskuvaus Jarmo)

-- avustajan tunnit eivät riitä [asiakkaan nimi] mukaan harrastuksiin. Keskusteltu ja ohjeistettu, mikäli asiakas haluaa esimerkiksi käydä konserteissa, voi hän hakea lisätunteja kunkautta kohden. Asiakasta ja avustajaa on ohjeistettu olemaan Heta -liittoon yhteydessä -- (Asiakaskertomus ensimmäiseltä kotikäynniltä 5.4.2017)

Tapauksessa tehtiin vastaavalla kokoonpanolla toinen kotikäynti lähes puolitoista kuukautta ensimmäisen kotikäynnin jälkeen. Myös toisella kotikäynnillä keskus- 
teltiin siitä, miten Jarmo voisi organisoida henkilökohtaisen avustajan tunnit siten, että ne riittäisivät paremmin. (Tapauskuvaus Jarmo)

\section{-- Asiakkaan mukaan todellinen avun tarve on 10 tuntia päivässä -- Ohjeistettu avus- tajaa tutustumaan kunnan vammaispalve- lun sivuihin, jossa tietoa henkilökohtaisesta avusta - sosiaaliohjaaja jättänyt asiakkaalle avustajaehdokkaan työhakemuksen, jotta asiakas voi olla häneen yhteydessä mahdol- lisen haastattelun sopimiseksi -- keskusteltu siitä, että -- (Asiakaskertomus toiselta kotikäynniltä 26.5.2017)}

Kokonaisuudessaan prosessi kesti hieman alle kolme kuukautta. Lopullisella päätöksellä henkilökohtaista apua myönnettiin hieman vähemmän kuin Jarmo alun perin haki. Prosessi kuvaa, miten merkityksellisistä asioista vammaissosiaalityössä tehdään päätöksï sekä asiakkaan arjen sujumisen että palvelujärjestelmän taloudellisten resurssien näkökulmasta. Asiakkaalta edellytetään toimijuutta tarpeidensa ilmaisemisessa ja palvelujensa käytön organisoimisessa sekä sosiaalityöntekijältä vankkaa asiantuntijuutta ja ammatillista toimijuutta. Osa asiakkaista tarvitsee runsaasti henkilökohtaista opastusta palvelujen vaikuttavaan käyttöön. Jarmon tapauksessa työntekijät antoivatkin asiantuntijuutensa käytettäväksi asiakkaan tilanteen ratkaisemiseksi (myös Kokko 2018, 128).

Yhteistyöhön perustuvaan toimintaan sisältyy asiakkaan avoin informointi hänen mahdollisuuksistaan, oikeuksistaan sekä erilaisista vaihtoehdoista ja niiden vaikutuksista prosessin eri vaiheissa. Jaanan tapauksessa tämä ei näyttänyt toteutuneen. Asiakasdoku- menttien kirjausten perusteella Jaana ei ollut saanut sosiaalityöntekijältään tietoa mahdollisuudesta hakea kotiin järjestettävää maksutonta palveluasumista, vaikka myöhemmin tehdyssä päätöksessä viitattiin tarpeen tulleen esille jo puoli vuotta aikaisemmin palvelusuunnitelmaa tehtäessä. Dokumenttien perusteella herää kysymys siitä, tehtiinkö tapauksessa palvelutarpeen arviointi liian suppeana. Palvelusuunnitelmassa Jaanan kuvattiin tarvitsevan apua vain kodin ulkopuolella liikkuessaan, siivouksessa ja pyykinpesussa, mutta lopulliseen päätökseen oli kirjattu Jaanan tarvitsevan toisen henkilön apua "kaikissa päivittäisissä toimissaan”.

Jaanan prosessi alkoi tosiasiallisesti jo kesäkuun alussa tapahtuneesta palvelusuunnitelman laatimisesta. Jaana oli alun perin käynnistänyt prosessin, koska koki ongelmalliseksi henkilökohtaisen avun järjestämisen ostopalveluna ja toivoi sen tilalle työnantajamallia. Vaihdos työnantajamalliin kirjattiinkin palvelusuunnitelmaan. Mahdollisesta palveluasumisesta ei palvelusuunnitelmaan kirjattu mitään. Neljä ja puoli kuukautta myöhemmin Jaana jätti hakemuksen palveluasumisesta kuvaten yksityiskohtaisesti laajaa palvelutarvettaan ja etenevää sairauttaan. Myönteinen päätös palveluasumisesta tehtiin joulukuun alussa palvelupäälikön allekirjoittamana ja sosiaalityöntekijän valmistelemana. Perusteluina päätöksessä viitattiin kesäkuussa arvioituun palvelutarpeeseen. (Tapauskuvaus Jaana)

Asiakaslähtöisessä yhteistyösuhteessa asiakkaan ja työntekijän välinen yhteinen työskentely asiakasprosessin eri vaiheissa nousee merkitykselliseksi. Kuitenkin vain yhdessä aineiston tapauksista asiakkaan ja työntekijän oli do- 
kumentoitu esimerkiksi tehneen hakemuksen yhdessä, vaikka osassa muitakin prosesseja tämä olisi ollut hyödyllistä. Yhteistyössä tehty hakemus nivoutuu vahvemmin osaksi muuta prosessia ja heijastuu myönteisesti prosessin myöhemmissä vaiheissa.

Anssi haki henkilökohtaisen avun lisätunteja erityisesti työssä avustamiseen. Anssia auttoi hakemuksen tekemisessä kotikäynnin tehnyt vammaispalveluohjaaja. Täytettävä hakemuslomake oli 8 sivun mittainen. Muntamaa viikkoa myöhemmin tehdyllä päätöksellä Anssin henkilökohtaisen avun palvelun tuntimäärää nostettiin. Mahdollisuus hakemuksen tekemiseen yhdessä työntekijän kanssa todennäköisesti sujuvoitti koko prosessia. Anssin tapauksessa myös moniportainen päätöksentekoprosessi oli sujuva. (Tapauskuvaus Anssi)

Viime aikoina korostetun osallistavan kirjaamisen näkökulmasta on olennaista, että myös yhteinen työskentely dokumentoidaan. Aineiston palvelusuunnitelmat oli laadittu asiakkaan ja työntekijän välisissä kohtaamisissa, mutta niiden varsinainen yhdessä työstäminen ei tullut dokumenttien kirjauksista esille.

\section{TyÖNTEKIJÄN TOIMIJUUS JA LAADUKAS DOKUMENTOINTI}

Vaikka sosiaalityön käytäntöjen taustalla vaikuttavat organisaatiot, tarvitaan asiakaslähtöisyyden toteutumisessa aina sitoutuneita ammattilaisia (Beresford \& Croft 2004). Aineistossamme yksittäisen työntekijän asiakaslähtöistä toimintaa tai työtapaa kuvaavat teot liittyivät työntekijän ammatillis-eettiseen toimijuuteen ja laadukkaaseen doku- mentointiin sen osana. Osassa tapauksia työntekijä oli dokumenttien perusteella ottanut hakemuksen joustavasti vastaan suullisesti, puhelimitse tai sähköpostitse pyytämättä erillistä kirjallista hakemusta, toiminut päätöksentekoprosessissa erityisen nopeasti tai antanut asiakkaalle runsaasti henkilökohtaista ohjausta ja neuvontaa useampia tapaamisia tarvittaessa järjestäen. Yksittäistapauksessa työntekijä oli dokumentoinut myös prosessiin sisältyviä omia vastuitaan ja toimintaansa.

Laadukas dokumentointi tarkoittaa muun muassa dokumentoinnin eheyttä ja täsmällisyyttä, sillä kirjaamatta jättäminen voi jättää merkityksellistä tietoa piiloon (Kuusisto-Niemi \& Kääriäinen 2005; Kääriäinen 2016). Esimerkiksi palvelusuunnitelmat olivat aineistossamme kyllä yleensä muodollisesti tehtyjä, mutta jättivät usein ainakin osittain avoimeksi sekä prosesseissa käsiteltävät asiat että prosessin etenemisen. Suunnitelmissa lueteltiin asiakkaan diagnoosit, kuvattiin vaihtelevalla laajuudella asiakkaan tilannetta ja toimintakykyä, lueteltiin asiakkaan palvelut sekä kirjattiin lyhyesti asiakkaan toiveet palvelujen järjestämiseksi. Sen sijaan yhteisesti sovittuja tavoitteita, tavoitteiden saavuttamisen edellyttämiä keinoja ja vastuita tai sitä, miten prosessi käytännössä etenee, ei ollut kattavasti dokumentoitu. Myös työntekijän oman toiminnan dokumentointi oli pääsääntöisesti vähäistä (myös Kivistö 2014).

Aineiston dokumentoinnissa olleisiin aukkoihin saattavat vaikuttaa organisaation viralliset tai epäviralliset ohjeistukset siitä, mitkä asiat on tuotava tiimiin tai esimiehen kanssa neuvoteltaviksi. Tällainen päätöksenteon mo- 
niportaisuus pirstaloittaa prosessia ja kapeuttaa työskentelyn suunnitelmallisuutta ja työntekijän oman harkinnan käyttöä (myös Romakkaniemi ym. 2018). Palvelutarpeen selvittämisen ja päätöksenteon eriytyminen toisistaan vaatii myös selvityksen tehneen työntekijän vankkaa osaamista ja vahvaa toimijuutta, jotta hän kykenee sekä suullisesti että dokumentoiden perustelemaan palveluiden järjestämisen tarpeen. On muistettava, että mahdollisissa ristiriitatilanteissa sosiaalityön etiikka edellyttää työntekijän asettautumista heikompien puolelle (Kananoja 2017), ja että dokumentointi toimii myös työntekijän välineenä asiakkaan tarpeiden ja oikeuksien perustelemisessa (myös Kivistö 2014). Osassa aineiston tapauksia työntekijät organisaation eri tasoilla kykenivätkin käyttämään toimijuuttaan myös moniportaisessa järjestelmässä (myös Närhi ym. 2014). Nopeimmillaan myönteinen päätös saattoi valmistua yhdessä päivässä.

\begin{abstract}
Päätökseen oli kirjattu Saaran soittaneen edellisenä päivänä vammaispalveluun ja pyytäneen henkilökohtaisen avun lisätunteja uuden harrastuksen aloittamiseksi. Sosiaalityöntekijä oli ottanut hakemuksen suullisesti puhelimessa vastaan ja valmisteli päätöksen välittömästi. Myös päätöksen tehneen palvelupäälikön osuus saatiin prosessiin mukaan nopeasti ja jo seuraavana päivänä Saaralle myönnettiin kymmenen lisätuntia kuukaudessa. (Tapauskuvaus Saara)
\end{abstract}

Asiakasdokumenteista käsin tarkasteltuna Saaran tapaus kuvaa joustavaa ja nopeaa päätöksentekoa sekä myönteistä harkintaa asiakkaan osallistumisen mahdollistamiseksi. Poikkeuksellisesta sujuvuudestaan huolimatta tapaus jättää kuitenkin kaipaamaan dokumentoituja perusteluja seuraaviin kysymyksiin: Mikä teki Saaran tilanteesta muihin aineiston tapauksiin verrattuna sellaisen, että se pystyttiin ratkaisemaan yhden vuorokauden aikana? Entä tuliko Saara tosiasiallisesti autetuksi nopean prosessin ja myönteisen päätöksen myötä? Kaikissa aineiston tapauksissa työntekijän asiakaslähtöinen toiminta prosessin alkupäässä ei johtanut kokonaisuutena sujuvaan prosessiin. Asiakaslähtöisyyden kannalta työntekijöiden vahvaa toimijuutta kaivataankin läpi koko asiakasprosessin ja asiakkaisiin yhdenvertaisesti kohdentuen.

\section{DOKUMENTOITU ASIAKASLÄHTÖISYYS}

Tapaustutkimuksen tuottaman tiedon avulla voidaan käytäntöjen kehittämiseksi paljastaa jotain rutiineissa aiemmin piiloon jäänyttä (Laine ym. 2007; Yin 2014). Havaintojemme perusteella sekä vammaissosiaalityön prosessien että prosessien dokumentoinnin asiakaslähtöisyydessä on kehitettävää.Vammaissosiaalityön päätöksenteon tosiasiallinen toteutuminen usein ylemmällä tasolla voi heikentää työntekijöiden ryhtymistä kumppanuuteen asiakkaan kanssa sekä työntekijän sitoutumista asiakkaaseen myös dokumentoidusti (myös Beresford \& Croft 2004). Prosessien pitkittyessä myös managerialismin hengessä tavoiteltu kustannustehokkuus kyseenalaistuu. Dokumentoinnissa on lisäksi aukkoja (myös Savaya 2010), mikä on harmillista paitsi asiakaslähtöisyyden, myös sosiaalityön ammatillisuuden todentamisen näkökulmasta. Havainnoissamme on kyse sosiaalityön sosiaalisista rakenteista, joihin liittyviä toimintakulttuureita itse ylläpidämme, 
mutta joihin voimme toimijoina myös itse vaikuttaa (ks. Giddens 1984; 1989). Rakenteistumiseen vaikuttaminen edellyttää kuitenkin tietoisuuden lisäämistä (Wheeler-Brooks 2009).

Asiakkaan ja organisaatiota edustavan ammattilaisen välisen suhteen laatu on merkityksellinen sen kannalta, millainen prosessista lopulta muodostuu (Kananoja 2017, 190). Kuitenkin, vaikka sosiaalityöntekijät toteuttavat asiakaslähtöisyyttä käytännössä, tulee organisaatiotasolla varmistua siitä, että prosesseissa tehtyjen tapauskohtaisten valintojen on mahdollista olla harkittuja, perusteltuja, yhdenvertaisia, oikea-aikaisia ja dokumentoituja. Asiakaslähtöisyyden ideologiaa ei voi vain abstraktina retoriikkana valuttaa organisaation ylätasolta alaspäin, vaan organisaatioissa tulee yhdessä työntekijöiden ja asiakkaiden kanssa määritellä, mitä asiakaslähtöisyys tarkoittaa ja miten sitä käytännössä toteutetaan (Carr 2007; Närhi ym. 2014; myös Laitila 2010; Kokko 2018). Asiakaslähtöisyys voi tarkoittaa muun muassa rakenteellista sitoutumista läpinäkyviin ja mahdollisimman nopeisiin prosesseihin erityisesti kiireellisissä asioissa, turhan byrokratian vähentämistä, systemaattista yhteydenpitoa asiakkaisiin sekä resurssien ja välineiden tarjoamista työntekijöille asiakassuhteiden luomiseen, ylläpitoon ja huolelliseen dokumentointiin.

Sosiaalityön prosessin vaiheistaminen teoriassa ja lainsäädännössä on jakanut myös dokumentoinnin osa-alueisiin. Lisäksi managerialistinen, tehokkuutta korostava diskurssi (esim. Närhi ym. 2014) on synnyttänyt tarpeen tuottaa dokumentteja sosiaalityön tehokkuut- ta osoittavina suoritteina. Riitta-Liisa Kokko (2018) on kuvannut ilmiötä "toimenpidekeskeisenä" työorientaationa. Kuitenkin, vaikka sosiaalityön prosessi nähdään usein sosiaalityön työvaiheina, asiakaslähtöisyyden näkökulmasta huomio tulee kiinnittää nimenomaan asiakkaaseen ja hänen tilanteeseensa. Lisäksi prosessia on välttämätöntä tarkastella kokonaisuutena, sillä prosessin yksittäiset vaiheet ja niiden yhteydessä suoritetut teot saavat oikeutuksensa vasta osana prosessikokonaisuutta ja sosiaalityön tehtävää (Kemppainen ym. 2010, 27; Kananoja 2017, 190).

Ilman kokonaisvaltaista tarkastelua tapauskohtaiset prosessit voivat näyttäytyä jopa virheellisesti asiakaslähtöisinä. Kuvaa aidosta asiakaslähtöisyydestä ei saavuteta tarkastelemalla prosessin lopputuloksena tehtyä myönteistä päätöstä tai kokonaistakaan prosessia pelkästään tietojärjestelmään tehdyn "teknisen" vireillepanon ja päätöksen muodostamalla hallinnollisella aikajanalla. Asiakaslähtöisyyttä arvioitaessa tulee tarkastella koko prosessia kaikkine tapahtumineen ja toimintatapoineen, peilata sitä asiakkaan elämänkulkuun ja elämäntilanteeseen sekä huomioida asiakkaan tilanne ennen prosessia ja ennakoida sen jatkumista. Asiakkaan elämään kiinnittyminen tarkoittaa asiakkaan äänen entistäkin vahvempaa esille tuomista myös asiakasdokumenteissa (myös Günther ym. 2013). Asiakaslähtöisyyden näkökulmasta dokumentoinnin tulisi kohdistua myös asiakkaan kokemukseen asiakkuudestaan ja palveluprosessistaan sekä tehdä prosessit ja niihin sisältyvät kohtaamiset eheinä näkyviksi (myös Laitinen \& Niskala 2016; Romakkaniemi ym. 2018). 
Tulostemme sovellettavuutta arvioitaessa on huomioitava aineistomme pienuus ja sen rajautuminen kahdelle paikkakunnalle. Tulostemme rajoina on myös tunnistettava, ettei niissä aineiston ajallisesta ulottuvuudesta johtuen vielä näy sosiaalityön dokumentoinnin kansallisen kehittämisen vaikutukset. Myös vammaissosiaalityön kuormittunut tilanne (ks. Laisi ym. 2016) vaikuttaa väistämättä työntekijöiden dokumentointimahdollisuuksiin. Aineistomme rajoista huolimatta siitä löytyi tapauskohtaisen vaihtelun lisäksi myös samankaltaisuuksia sekä havaintoja, jotka vastaavat aiemman tutkimuksen tuloksia (esim. Kivistö 2014). Tutkimuksemme ei niinkään ota kantaa siihen, ovatko vammaissosiaalityön asiakasprosessit asiakaslähtöisiä, vaan siihen, millaisen kuvan asiakaslähtöisyydestä asiakasdokumenttien perusteella saa.

Tutkimuksemme tuottaa uutta tietoa vammaissosiaalityön prosessien asiakaslähtöisyydestä. Vammaissosiaalityön prosesseja ei ole aiemmin tutkittu kokonaisuuksina asiakasdokumentteja aineistona käyttäen. Vastauksena ensimmäiseen tutkimuskysymykseen toteamme, että vammaissosiaalityön prosessit etenevät asiakasdokumenttien antaman informaation perusteella asiakaslähtöisyyden näkökulmasta vaihtelevasti. Yhtäältä osa prosesseista etenee sujuvasti asiakkaiden muuttuviin tarpeisiin tarvittaessa nopeastikin vastaten. Toisaalta osa prosesseista on monivaiheisia ja pitkiä, eivätkä prosessien taustalla olevat valinnat tule dokumentoiduiksi. Toiseen tutkimuskysymykseen vastauksena tiivistämme asiakaslähtöisyyden edellytykset organisaation näkökulmasta asiakkaan ja ammattilaisen toimimisen mahdollistamiseksi sekä prosessien ja dokumentoinnin asiakaslähtöisten rakenteiden varmistamiseksi. Työntekijän näkökulmasta asiakaslähtöisyys edellyttää vahvaa ammatillis-eettistä toimijuutta sekä laadukasta dokumentointia. Tilausta on erityisesti asiakkaan ja ammattilaisen välisen dialogin sekä yhteisen työskentelyn dokumentoimiselle. Asettamamme viimeinen tutkimuskysymys koski vammaissosiaalityön asiakaslähtöisyyden kokonaiskuvaa. Esitämme, että vammaissosiaalityön prosessit näyttäytyvät asiakaslähtöisyysretoriikasta huolimatta orientaatioltaan varsin järjestelmälähtöisiltä, mikä tulee esille muun muassa osan prosesseista moniportaisuutena, pitkittymisenä ja asiakkaan vastuuttamisena. Aineistomme tapauskohtaisiin prosesseihin voi sisältyä hyvää, jopa erinomaista sosiaalityötä, mutta se ei tule asiakasdokumenteissa riittävällä tavalla näkyväksi. Kokonaisuutena tuloksemme herättävätkin kysymään: onko asiakaslähtöisyys totta vasta, jos ja kun se dokumentoidaan?

Voidaan toki pohtia, mitä asiakaslähtöisyydestä kyetään sanomaan viranomaisten kirjoittamien asiakirjojen perusteella tilanteessa, jossa kaikkea prosesseihin sisältyvää toimintaa ei ole mahdollista eikä tarkoituksenmukaista dokumentoida. Mielestämme sosiaalityö voi kuitenkin olla aidosti asiakaslähtöistä vain, jos myös dokumentointi osoittaa näin olevan ja jos dokumentointi itsessään on asiakaslähtöistä. Asiakaslähtöisyys ei ensisijaisesti tarkoita dokumentoinnin merkittävää laajentamista, vaan ennemmin tietoisesti harkittua dokumentointia (myös Günther ym. 2013). Tuloksiamme voidaan hyödyntää sosiaalityön käytäntöjen ja dokumentoinnin asiakaslähtöisessä kehittämisessä. Keskeistä on ylipäänsä lisätä ja laajentaa sosiaali- 
työn dokumentointia koskevaa tutkimusperusteista keskustelua.Vaikka asiakasdokumentit kykenevät tuottamaan vain rajallisen kuvan, on dokumentointi keskeinen jälki, jonka perusteella sosiaalityötä ja sen asiakaslähtöisyyttä arvioidaan.

\section{RAHOITUS}

Tämä tutkimus on toteutettu Euroopan sosiaalirahaston tuella (Osallisuuden varmistaminen ja syrjäytymisen ehkäiseminen vammaissosiaalityön asiakasprosessissa -hanke 2016-2019).

\section{ViITTEET}

1 Sosiaalihuollon määrämuotoiseen kirjaamiseen liittyvät Kansakoulu -hankkeet.

\section{KirJallisuUs}

Autio, Anu \& Nurmi-Koikkalainen, Päivi (2015) Vammaispalveluiden asiakassuunnitelmat asiakasosallisuuden rakentajina. Janus 23 (2), 232-238.

Beresford, Peter \& Croft, Suzy (2004) Service users and practitioners reunited: the key component for social work reform. British Journal of Social Work 34 (1), 53-68. https://doi.org/10.1093/bjsw/ bch005

Bryman, Alan (2008) Social research methods. Third edition. Oxford: Oxford University Press.

Carr,Sarah (2007) Participation, power,conflict, and change:Theorizing dynamics of service user participation in the social care system of England and Wales. Critical Social Policy 27 (2), 266-276. https:// doi.org/10.1177/0261018306075717

Compton, Beulah \& Galaway, Burt \& Cournoyer, Barry R. (2005) Social work processes. Belmont: Books/Cole.

Doyle, Andrea (2010) History of research on process relevant to clinical social work. Clinical Social Work Journal 39, 68-78. https://doi.org/10.1007/s10615-0100296-z

Eriksson, Päivi \& Koistinen, Katri (2005) Monenlainen tapaustutkimus. Kuluttajatutkimuskeskuksen julkaisuja 4/2005. Helsinki: Kuluttajatutkimuskeskus.

Eubanks, Virginia (2017) Automating inequality. How high-tech tools profile, police, and punish the poor. New York: St Martins` Press.

Giddens, Anthony (1984) The constitution of society: Outline of the theory of structuration. Cambridge: Polity Press.

Giddens, Anthony (1989) Sociology. Oxford: Polity Press.

Gillingham, Philip \& Graham, Timothy (2016) Designing electronic information systems for the future: social workers and the challenge of new public management. Critical Social Policy 36 (2), 187-204. https://doi. org/10.1177/0261018315620867

Günther, Kirsi \& Raitakari, Suvi \& Juhila, Kirsi \& Saario, Sirpa \& Kaartamo, Riina \& Kulmala, Anna (2013) Asiakaslähtöisyys. Vakavaa mielen sairautta sairastavien nuorten aikuisten kuntoutuskurssilla. Etnometodologinen tapaustutkimus. Tampere: Muotialan asuin- ja toimintakeskus ry.

Günther, Kirsi (2015) Asiakasdokumentaatio arviointina mielenterveystyön arjessa. Tutkimus ammatillisesta kirjaamisesta. Acta Electronica Universitatis Tamperiensis 1602. Tampere: Tampereen yliopisto.

Juhila, Kirsi (2006) Sosiaalityöntekijöinä ja asiakkaina. Sosiaalityön yhteiskunnalliset tehtävät ja paikat. Tampere:Vastapaino.

Järvikoski, Aila \& Hokkanen, Liisa \& Härkäpää, Kristiina (2009) Asiakkaan äänellä. Odotuksia ja arvioita vaikeavammaisten lääkinnällisestä kuntoutuksesta. Helsinki: Kuntoutussäätiö.

Kananoja, Aulikki (2017) Asiakastyön yleiset lähtökohdat sosiaalialalla. Teoksessa Aulikki Kananoja \& Martti Lähteinen \& Pirjo Marjamäki (toim.) Sosiaalityön käsikirja. 4. uudistettu laitos. Tallinna: Tietosanoma Oy, 171-192.

Kemppainen, Tarja \& Kostamo-Pääkkö Kaisa \& Niskala, Asta \& Ojaniemi, Pekka 
\& Vesterinen, Kerttu (2010) Sosiaalityön vaikuttavuuden arvioinnin ensiaskelet Lapista. Tutkimus sosiaalitoimistojen työn vaikuttavuudesta. Rovaniemi: Pohjois-Suomen sosiaalialan osaamiskeskus.

Kemppainen, Tarja \& Arola, Heli \& Helavirta, Susanna \& Martin, Maria \& Niskala, Asta \& Seppälä, Leena \& Tiitinen, Laura \& Vuorijärvi, Petri (2018) Sosiaalialan osaaminen Lapissa. Teoksessa Tarja Juvonen \& Jari Lindh \& Anneli Pohjola \& Marjo Romakkaniemi (toim.) Sosiaalityön muuttuva asiantuntijuus. Sosiaalityön tutkimuksen vuosikirja. EU: UNIpress, 184-210.

Kivistö, Mari (2014) Kolme ja yksi kuvaa osallisuuteen. Monimenetelmällinen tutkimus vaikeavammaisten ihmisten osallisuudesta toimintana, kokemuksena ja kielenkäyttönä. Acta Universitatis Lapponiensis 283. Rovaniemi: Lapin yliopistokustannus.

Kivistö, Mari \& Heini, Annina \& Kontu, Katariina \& Kunttu, Katriina \& Lappalainen, Tiina \& Lindroos, Nelli \& Ronimus, Heli \& Sjöblom, Stina (2019). Asiakasosallisuuden toteutuminen ja digitalisaation mahdollisuudet vammaissosiaalityön asiakasprosessissa. Kuntoutus 42 (1), 34-40.

Kokko, Riitta-Liisa (2018) Asiakaslähtöisyys tavoitteena työllistymistä edistävässä monialaisessa yhteispalvelussa. Janus 26 (2), 123-139. https://doi.org/10.30668/ janus. 66411

Kuusisto-Niemi, Sirpa \& Kääriäinen, Aino (2005) Hiljaisen tiedon vallasta näkyvän tiedon valtaan - puheenvuoro tiedon näkyväksi tekemisen puolesta. Janus 13 (4), 452-460.

Kääriäinen, Aino (2003) Lastensuojelun sosiaalityö asiakirjoina. Dokumentoinnin ja tiedonmuodostuksen dynamiikka. Helsinki: Helsingin yliopisto.

Kääriäinen, Aino (2016) Sosiaalityön dokumentointi: suhde tietoon ja toimintaan. Teoksessa Maritta Törrönen \& Kaija Hänninen \& Päivi Jouttimäki \& Tiina Lehto-Lunden \& Petra Salovaara \& Minna Veistilä (toim.) Vastavuoroinen sosiaalityö. Helsinki: Gaudeamus, 189-198.

Laine Markus \& Bamberg Jarkko \& Jokinen Pekka (2007) Tapaustutkimuksen käytäntö ja teoria. Teoksessa Markus Lai- ne \& Jarkko Bamberg \& Pekka Jokinen (toim.) Tapaustutkimuksen taito. Helsinki: Gaudeamus, 9-40.

Laisi, Nina \& Lappalainen, Tiina \& Vauramo, Mirja (2016) Selvitys vammaispalveluiden sosiaalialan ammattilaisten näkemyksistä. Invalidiliitto ry \& Talentia ry. http://www.talentia.fi/files/6051/Selvitys_vammaispalveluiden_sosiaalialan_ ammattilaisten_nakemyksista_Talentia_ ja_Invalidiliitto.pdf Luettu 10.3.2018

Laitila, Minna (2010) Asiakkaan osallisuus mielenterveys- ja päihdetyössä. Fenomenografinen lähestymistapa. Publications of the University of Eastern Finland. Dissertations in health sciences 33. Kuopio: Itä-Suomen yliopisto.

Laitinen, Merja \& Niskala, Asta (2016) Sosiaalityön suhde asiakkuuteen. Teoksessa Merja Laitinen \& Asta Niskala (toim.) Asiakkaat toimijoina sosiaalityössä. Tampere:Vastapaino, 9-16.

Laki sosiaalihuollon asiakasasiakirjoista 254/2015.

Lindh, Jari \& Hautala, Sanna \& Romakkaniemi, Marjo (2018) Sosiaalityön asiantuntijuus heikoimmassa asemassa olevien kanssa tehtävässä työssä. Teoksessa Tarja Juvonen \& Jari Lindh \& Marjo Romakkaniemi \& Anneli Pohjola (toim.). Sosiaalityön muuttuva asiantuntijuus. Tallinna: UniPress, 39-65.

Niemi, Petteri (2016) Hyvä, paha valta. Teoksessa Merja Laitinen \& Asta Niskala (toim.) Asiakkaat toimijoina sosiaalityössä. Tampere:Vastapaino, 31-54.

Norlamo-Saramäki, Tuija (2009) Asiakaslähtöisyyden ristiaallokossa. Ammatillinen lisensiaatin tutkimus. Helsingin yliopisto. http://www.sosnet.fi/loader. aspx?id $=3 \mathrm{~d} 33 \mathrm{~d} 245-6 \mathrm{a} 68-498 \mathrm{f}-8 \mathrm{e} 17-\mathrm{db}-$ 3d3a2b589b Luettu 3.1.2019

Närhi, Kati \& Kokkonen, Tuomo \& Matthies, Aila-Leena (2014) Asiakkaiden osallisuus ja työntekijöiden harkintavalta palvelujärjestelmässä. Janus 2 (3), 227-244.

Oliver, Michael \& Sapey, Bob \& Thomas Pam (2012) Social work with disabled people. Fourth edition. Basingstoke: Macmillan. https://doi.org/10.1007/978-1137-02427-5

Pohjola, Anneli (2017) Asiakkaan pitkä tie palveluihin vaikuttajaksi. Teoksessa Anneli Pohjola \& Maarit Kairala \& Hannu 
Lyly \& Asta Niskala (toim.) Asiakkaasta kehittäjäksi ja vaikuttajaksi. Tampere:Vastapaino, 308-325.

Poikela, Ritva (2010) Asiakassuunnitelma asiakaslähtöistä auttamista tavoitteellistamassa. Kohteen rakentumisen moniääninen menetelmä. Helsinki: Helsingin yliopisto.

Reamer, Fredric G. (2017) Evolving ethical standards in the digital age. Australian Social Work 70 (2), 148-159. https://doi. org/10.1080/0312407X.2016.1146314

Romakkaniemi, Marjo \& Lindh Jari \& Laitinen Merja (2018) Nuorten aikuisten osallisuus ja sosiaalinen kuntoutus Lapissa. Sosiaali- ja terveysturvan tutkimuksia 147. Helsinki: Kela.

Romakkaniemi, Marjo \& Könkkölä, Kalle \& Martin, Marjatta \& Lappalainen, Tiina (2018) Vammaispalvelun sosiaalityön asiantuntijuus on turvattava. Yhteiskuntapolitiikka 28 (3), 338.

Salovaara, Susi (2018) Tietojärjestelmät osana lastensuojelun tiedonmuodostusta. Pro gradu -tutkielma. Rovaniemi: Lapin yliopisto. http://lauda.ulapland.fi/handle/10024/63248 Luettu 3.1.2019

Savaya, Rick (2010) Enchancing student awareness of the importance of full and accurate documentation in social work practice. Social Work Education 29 (6), 660-669. https://doi. org/10.1080/02615470903552006

Sosiaalihuollon asiakaslaki (812/2000).

Sosiaalihuoltolaki 1301/2014.

Talentia (2017) Arki, arvot ja etiikka. Sosiaalialan ammattihenkilön eettiset ohjeet. https://talentia.e-julkaisu.com/2017/ eettiset-ohjeet/docs/Talentia_Etiikkaopas_2017.pdf Luettu 3.1.2019
Tarvainen, Merja (2017) Palveluiden ydinoletukset ja muuttuva asiakkuuskäsitys. Teoksessa Anneli Pohjola \& Maarit Kairala \& Hannu Lyly \& Asta Niskala (toim.) Asiakkaasta kehittäjäksi ja vaikuttajaksi. Tampere:Vastapaino, 38-57.

Tiililä, Ulla (2007) Tekstit viraston työssä: Tutkimus etuuspäätösten kielestä ja konteksteista. Suomalaisen kirjallisuuden seuran toimituksia 1108. Helsinki: Suomalaisen kirjallisuuden seura.

Toikko, Timo (2009) Tapauskohtainen sosiaalityö. Teoksessa Mikko Mäntysaari \& Anneli Pohjola \& Tarja Pösö (toim.) Sosiaalityö ja teoria. Juva: PS-kustannus.

Tuomi, Jouni \& Sarajärvi, Anneli (2009) Laadullinen tutkimus ja sisällönanalyysi. Helsinki:Tammi.

Tuusa, Matti (2005) Sosiaalityö ja työllistäminen. Kuntouttavan sosiaalityön ammattikäytännöt kuntien aktivointi- ja työllistämispalveluissa. Ammatillinen lisensiaatin tutkimus. http://www.sosnet. fi/loader.aspx?id $=596 \mathrm{ad} 5 \mathrm{e} 0-$ facd $-45 \mathrm{cc}-$ 94a1-8e688b1f1851 Luettu 3.1.2019

Vammaispalvelulaki 1987/380.

Wheeler-Brooks, Jennifer (2009) Structuration theory and critical consciousness: Potential applications for social work practice. Journal of Sociology \& Social Welfare 1 (34), 123-140.

Yin, Robert (2014) Case study research. Design and methods. Thousand Oaks: Sage Publications. 